\title{
Exploration of Lignocellulolytic Microbes in Oil Palm Rhizosphere on Peat Soils and Their Respiration Activities
}

\author{
HAPPY WIDIASTUTI ${ }^{1}$, SISWANTO ${ }^{1}$, DARMONO TANIWIRYONO ${ }^{1}$, HERU BAGUS $^{2}$ \\ PULUNGGONO ${ }^{2}$, SYAIFUL ANWAR ${ }^{2}$, BASUKI SUMAWINATA ${ }^{2}$, HUSNI MUBAROK $^{3}$, AND \\ SUPIANDI SABIHAM ${ }^{2}$
}
${ }^{1}$ Indonesian Research Institute for Biotechnology and Bio-industry, and Indonesian Oil Palm Society (MAKSI), Bogor, Indonesia;
${ }^{2} I P B$ University, and Peatland Society of Indonesia (HGI), Bogor, Indonesia; ${ }^{3}$ Agronomy Research, PT Astra Agro Lestari Tbk, Jakarta, Indonesia.

\begin{abstract}
Microbial respiration in peatlands plays a role in contributing $\mathrm{CO}_{2}$ emissions. Studies of microbial exploration and respiration on peat soils in oil palm plantations have not been widely reported. This study was aimed to explore lignocellulolytic microbes found in peat soils (planted with 12-year-old oil palm, and fern vegetation peat), and compared with that found in mineral soils. Exploration was done by growing the samples on specific medium for each group of microbial functions. Respiration activity of the obtained culture was then analyzed based on the oxidation of peroxidase catalysis using a chromogen substrate (tetramethylbenzidine) and measured using spectrophotometry at a wavelength of $450 \mathrm{~nm}$. The results showed that both in mineral (MS) and peat planted with oil palm (GS) in a depths of 0-20 cm, lignolytic fungi were found with a population of $17 \mathrm{x} 10^{2}$. Similar results were also found in peatland with fern vegetation (GNS) but at a depth of 20-40 cm. Lignolytic bacteria (related to methylene blue degradation) can be found on peat soils planted with oil palm at a depth of 0-60 $\mathrm{cm}$ and the population increases with increasing depth. This lignolytic bacteria was also found on peat soils with fern vegetation and mineral soils planted with oil palm. At a depth of $0-20 \mathrm{~cm}$ the population of lignolytic bacteria in non-oil palm peat is highest. Cellulolytic bacteria were isolated at a depth of 0-60 cm. Cellulolytic bacterial populations were highest in oil palm peat at all depths compared to other samples. Respiration analysis of several dominant isolates showed fairly high variation between microbial function groups and within the same function group. The lignolytic microbial group degrading methylene blue showed high respiration activity and varies greatly (0.19-1.85 MER). While the respiration activity of cellulolytic bacteria ranged from 0.45 to $0.62 \mathrm{MER}$.
\end{abstract}

Key words: lignolytic and cellulolytic microbes, microbial extracelluler respiration, peatlands

Respirasi mikroba di tanah gambut berperan dalam menyumbangkan emisi $\mathrm{CO}_{2}$. Studi tentang eksplorasi dan respirasi mikroba di tanah gambut di perkebunan kelapa sawit belum banyak dilaporkan. Penelitian ini bertujuan mengeksplorasi mikroba lignoselulolitik yang terdapat di tanah gambut dan tanah mineral yang ditanami kelapa sawit berumur 12 tahun. Eksplorasi dilakukan dengan menumbuhkan contoh pada medium spesifik masing masing kelompok fungsi mikroba. Pada tahap selanjutnya dari kultur murni yang diperoleh dilakukan analisis aktivitas respirasi berdasarkan oksidasi katalisis peroksidase menggunakan substrat kromogen (tetramethylbenzidine) dan diukur menggunakan spektrofotometri pada panjang gelombang $450 \mathrm{~nm}$. Hasil isolasi menunjukkan bahwa pada gambut sawit (GS) dan mineral (MS) kedalaman 0-20 cm dijumpai jamur lignolitik dengan populasi $17 \times 10^{2}$. Hasil yang sama juga dijumpai pada gambut dengan vegetasi paku-pakuan (GNS) namun pada kedalaman 20-40 cm. Bakteri lignolitik (pendegradasi methylene blue) dapat dijumpai pada tanah gambut yang ditanami kelapa sawit pada kedalaman 0-60 cm dan populasinya meningkat dengan bertambahnya kedalaman. Bakteri ini dijumpai juga pada tanah gambut dengan vegetasi paku-pakuan dan tanah mineral sawit. Pada kedalaman 0-20 cm populasi bakteri lignolitik di gambut non sawit adalah tertinggi. Bakteri selulolitik berhasil diisolasi pada kedalaman 0-60 cm. Populasi bakteri selulolitik adalah tertinggi di gambut sawit pada semua kedalaman dibandingkan dengan sampel lainnya. Analisis respirasi beberapa isolat dominan menunjukkan variasi yang cukup tinggi di antara kelompok fungsi mikroba dan di dalam kelompok fungsi yang sama. Kelompok mikroba lignolitik pendegradasi methylene blue menunjukkan aktivitas respirasi yang tinggi dengan variasi di antara isolat yang juga tinggi (0,19-1,85 MER). Sedangkan aktivitas respirasi bakteri selulolitik berkisar antara 0,45-0,62 MER.

Kata kunci: gambut, mikroba lignolitik dan selulolitik, respirasi mikroba ekstraseluler

Indonesia, which represents tropical peatlands, has an area of around 14.9 million hectares of peatlands

\footnotetext{
*Corresponding author: Phone: +62-; Fax: +62- ; Email: happywidiastuti@gmail.com
}

(Wahyunto et al. 2011) and based on 2008 data on peat conditions Indonesia stores the third largest carbon stock in the world (after Canada and Russia) of around 54,016 million tons (Joosten, 2009). However, if peatlands are cleared/ converted and/ or drained, the 
carbon presents in the peat material and plant biomass will be oxidized to $\mathrm{CO}_{2}$. On cleared land, for example for oil palm plantations, enhanced emissions of $\mathrm{CO}_{2}$ from autotroph (Ra-root) and heterotroph (Rhmicrobial decomposition activities of organic matter) is suspected.

The dynamics of peatland greenhouse gases involve $\mathrm{CO}_{2}$ uptake through photosynthesis and release through autotroph respiration from plants (roots), heterotroph respiration (microbes) and transport of dissolved and difficult-to-decompose organic matter (Jauhiainen et al.; Moore et al. 2013). Heterotrophic respiration is the decomposition of organic matter by microbes that produce $\mathrm{CO}_{2}, \mathrm{~N}_{2} \mathrm{O}$, and $\mathrm{CH}_{4}$. In this process the groundwater depth determines the boundary between aerobic conditions above and anaerobes at the bottom. Changes in water availability and water content in the substrate can change the structure of microbial communities that are sensitive to the availability of water and oxygen (Jaatinen et al. 2008). Organic polymers on the surface of peat decompose aerobically by bacteria and fungi and when the peat becomes saturated with water, a succession occurs so that anaerobic bacteria will decompose to produce $\mathrm{CH}_{4}$ by methanogenic microbial groups. Denitrifying bacteria will produce $\mathrm{N}_{2} \mathrm{O}$ in anaerobic conditions in the presence of nitrates. The depth of the ground water on peat is a major factor used to explain the dynamics of GHG flux in tropical peat in addition to the vegetation above it (IPCC 2014).

Soil respiration is the main source of atmospheric $\mathrm{CO}_{2}$ and its value is higher than fossil fuels. The rate of soil efflux at the surface of the soil is the sum of heterotroph (microbial decomposition) and autotroph (root) respiration where the root accounts for almost half the $\mathrm{CO}_{2}$ flux (Berger et al. 2010). In natural ecosystems, soil organic $\mathrm{C}$ consists of various carbon compounds which can be grouped in labile (dissolved organic C) and recalcitrant. Therefore differences in the organic soil $\mathrm{C}$ fraction will affect heterotrophic respiration due to the ease of decomposition and microbial preference. Non-recalcitrant substrates are probably temperature sensitive (Fierer et al. 2005; Davidson and Janssens 2006). Wang et al. (2014), based on a meta-analysis, revealed a $21 \%$ increase in heterotroph respiration with an increase in temperature of $2{ }^{\circ} \mathrm{C}$. However, a comprehensive analysis of the magnitude of $\mathrm{CO}_{2}$ emissions from total respiration in both autotrophs and heterotrophs in oil palm land on peat soils has not been widely reported.

The major microbes in peat related to decomposition are cellulolytic and lignolytic microbes. These microbial groups produce extracellular enzymes that can degrade cellulose or lignin. Those enzyme can be cellulase for cellulose, while and laccase, Mnperoxidase and Fe-peroxidase for lignin. Each microbe has the ability to decompose and so do the different respiration activities. Lignolytic microbes can be methylene blue degrading microbes caused by similarities or dissimilarities in the analysis of lignin degradation. Methylene blue degrading microbes are like Pseudomonas auroginosa (Eslami et al. 2017). This study was aimed to explore lignocellulolytic microbes found in peat soils (planted with 12-year-old oil palm, and fern vegetation peat), and compared with that found in mineral soils. Microbial populations of cellulose and lignin decomposition and the amount of respiration of several dominant lignocellulose isolates will be described.

\section{MATERIALS AND METHODS}

Research Location and Method of Sampling. Soil samples were taken from a 12 year old oil palm plantation in PT KTU (Kimia Tirta Utama), Pangkalan Pisang, Koto Gasib, Siak Regency, Riau, in February 2019. The peat maturity is Sapric. Samples were taken from 3 points for each habitat namely oil palm peat (GS), non oil palm peat (GNS), and nearby mineral soil (MS) at 3 depths namely 0-20 cm, 20-40 cm, and 40-60 $\mathrm{cm}$ with 3 replications so that the total sample were 27. The samples were taken non-sterile using a drill in the area of an oil palm which was approximately $1.5 \mathrm{~m}$ from the oil palm tree. Samples from non-palm peat (GNS) were samples taken on peat soils with fern vegetation. Soil samples after being taken were put in plastic bags after being labeled and stored in ice boxes to be brought to the laboratory.

Isolation and Characterization of Lignolytic and Cellulolytic Microbes. Microbes were isolated from soil samples by serial dilution, which were then grown in a selective medium based on microbial function groups. For bacteria, the sample suspension planted in the medium was $10^{-7}$ to $10^{-9}$ dilutions, while for fungi the dilution was $10^{-4}$ to $10^{-6}$. For the isolation of lignolytic fungi and lignolytic bacteria, guaiacol $(0,4 \mathrm{ml} / 1)$ and methylene blue $(25 \mathrm{mg} / \mathrm{l})$ medium were used respectively, while for the isolation of cellulolytic fungi and bacteria, CMC (2g/l) was added in the media.

Analysis of Lignolytic and Cellulolytic Microbial Respiration. Respiration analysis was 
carried out on selected dominant isolates following the method proposed by Zhou et al. (2010). This method utilizes the peroxidase activity of the key components (multi-heme c-type cytochromes) of the extracellular electron transfer network. The bacterial intrinsic peroxidase-catalyzed oxidation of chromogen (e.g., tetramethylbenzidine) resulted in a measurable color change correlated with the MER (microbial extracellular respiration) ability of the tested microorganisms.

\section{RESULTS}

Isolation and Characterization of Lignolytic and Cellulolytic Microbes. The microbes that have been isolated from three habitats are cellulolytic and lignolytic bacteria and lignolytic fungi as presented in Figure 1, while populations of each of those microbial functions group are presented in Table 1. Cellulolytic bacteria form a clear zone around the colony, while lignolytic bacteria change the color of the medium to yellow and other isolates show a bluer colony color which may indicate absorption of methylene blue inside the cell. The Table shows that in GS (peat-oil palm) at a depth of $0-20 \mathrm{~cm}$ cellulolytic bacteria, lignolytic bacteria, and lignolytic fungi were found, while at a depth of $20-40 \mathrm{~cm}$ only cellulolytic and lignolytic bacteria were found. The population of lignolytic bacteria was much higher compared to cellulolytic bacteria and its population actually increased with increasing depth, although lignin content of each depth was relatively similar.

In GNS soil (peat-non oil palm), lignolytic fungi were not found at a depth of $0-20 \mathrm{~cm}$, but found at a depth of $20-40 \mathrm{~cm}$. The population of lignolytic bacteria was very high at a depth of $0-20 \mathrm{~cm}$, but decreased with increasing depth and not found at 40-60 $\mathrm{cm}$ depth. Whereas the population of cellulolytic bacteria was almost the same at all depths although it was much lower compared to lignolytic bacteria. The content of celullase was higher with the increasing of depth. Lignolytic fungi were found only at a depth of $20-40 \mathrm{~cm}$.

In the mineral soil of oil palm at all depths, cellulolytic and lignolytic bacteria were found. However, lignolytic fungi were only found at a depth of $0-20 \mathrm{~cm}$. The population of lignolytic fungi was much lower than that of cellulolytic bacteria and lignolytic bacteria. The rasio of total fungal and bacteria of GS (peta-oil palm), GNS (peat-non oil palm), and MS (mineral-oil palm) was $1510^{-6}, 2410^{-7}$, and $3810^{-6}$. In this research the ratio is less than 1 and the bacteria is dominant compared to fungi.

Comparison between populations of lignolytic bacteria (degrading of methylene blue) in 3 habitats shows that the population in GNS (peat-non oil palm) is highest at $0-20 \mathrm{~cm}$ and decreases at subsequent depths. However, the population of these bacteria in oil palm mineral soils (MS) is higher compared to GS (peat-oil palm) especially at depths of 40-60 cm. The content of lignin was higher in GS (peat-oil palm) compared to those in MS (mineral-oil palm).

Cellulolytic bacterial population in GS (peat-oil palm) is slightly higher than MS (mineral-oil palm) and cellulolytic bacterial population is almost the same at a depth of 20-60 $\mathrm{cm}$ in all three habitats. The population of cellulolytic bacteria when compared to lignolytic bacteria is much lower at almost all depths in both GS (peat-oil palm), GNS (peat-non oil palm) and MS (mineral-oil palm).

Analysis of Lignolytic and Cellulolytic Microbial Respiration. Respiration analysis of

Table 1 Microbe population of each functional group in each habitat

\begin{tabular}{lcccc}
\hline $\begin{array}{c}\text { Sample } \\
\text { code }\end{array}$ & Depth (cm) & $\begin{array}{c}\text { Cellulolytic } \\
\text { bacteria (CMC) }\end{array}$ & $\begin{array}{c}\text { Lignolytic bacteria } \\
\text { (met blue) }\end{array}$ & $\begin{array}{c}\text { Lignolytic fungi } \\
\text { (guaiacol) }\end{array}$ \\
\hline GS & $0-20$ & $2.210^{6}$ & $1.310^{7}$ & $1710^{2}$ \\
& $20-40$ & $6510^{4}$ & $3310^{8}$ & 0 \\
& $40-60$ & $8210^{4}$ & $4.910^{9}$ & 0 \\
GNS & $0-20$ & $6710^{4}$ & $3.710^{12}$ & 0 \\
& $20-40$ & $5310^{4}$ & $9.310^{9}$ & $1710^{2}$ \\
& $40-60$ & $6510^{4}$ & 0 & 0 \\
MS & $0-20$ & $1.710^{6}$ & $610^{8}$ & $1710^{2}$ \\
& $20-40$ & $5510^{4}$ & $3.410^{9}$ & 0 \\
& $40-60$ & $6410^{4}$ & $5.510^{10}$ & 0 \\
\hline
\end{tabular}

Notes: GS (peat-oil palm), GNS (peat-non oil palm), MS (mineral-oil palm) 
several lignolytic and cellulolytic isolates is presented in Figure 2. The population of each isolate analyzed is presented in Table 2. The analysis was carried out on 3 functional groups microorganism namely cellulolytic bacteria, lignolytic bacteria, and lignolytic fungi. Respiration ability of each isolate varies both in the same functional group and between functional groups. In general, lignolytic fungi have the lowest respiration ability and are followed by cellulolytic bacteria.

Among the cellulolytic bacterial groups analyzed, their respiration ability showed quite wide variations. The respiration range for cellulolytic bacteria is between 0.222 microbial extracellular respiration (MER) (peat-oil palm 40-60 cm) to 0.655 MER (mineral-oil palm 0-20 cm). Similar results were also found in lignolytic bacteria. Lignolytic bacterial respiration has very wide variations ranging from 0.172 to 1.831 MER. Isolates derived from GNS (peatnon oil palm) at a depth of 40-60 cm have the highest respiration while the lowest respiration ability is isolates from MS (mineral-oil palm) isolated from a depth of $20-40 \mathrm{~cm}$.

The existence of lignolytic fungi of the three types of samples were very rare and found in only low population. Though from the isolates obtained, the ability of those two lignolytic fungi isolates had almost the same respiration activity ranging from 0.184 to 0.213 MER. This value when compared to those other isolates shows a fairly low respiration value.

\section{DISCUSSION}

The Table 1 shows that in GS (peat-oil palm) at a depth of $0-20 \mathrm{~cm}$ cellulolytic bacteria, lignolytic bacteria, and lignolytic fungi were found, while at a depth of 20-40 cm only cellulolytic and lignolytic bacteria were found. Differences in oxygen content in the soil are likely to cause this difference. The oxygen content was high in the surface and lower in the deeper layers. The population of lignolytic bacteria is much higher compared to cellulolytic bacteria and its population actually increases with increasing depth, although lignin content of each depth was relatively similar. Depth also strongly influenced microbial diversity and composition, while both depth and vegetation (oil palm and fern) exhibited significant impact on the archaeal communities. Microbial diversity was highest at the surface, where fresh leaf litter accumulates, and so higher nutrient supply is available.

The population of lignolytic bacteria is very high, but decreases with increasing depth and not found at the depths of $40-60 \mathrm{~cm}$. It might be that there is no correlation with the content of lignin since the lignin content was relatively similar in each depth. Meanwhile, the population of cellulolytic bacteria is almost the same at all depths although it is much lower compared to lignolytic bacteria. The content of celullase was higher with the increasing of depth. Lignolytic fungi are only found at a depth of $20-40 \mathrm{~cm}$. There was correlation between root weight and the oxygen concentration (Boggie 1977). It might be there are dynamic of water content that affect the oxygen content since the reduction of water content increases the oxygen content (Estop-Aragones et al. 2012). Plant roots affect the oxygen content since the root exclude the oxygen, in turn affect the microbial composition.

Table 2 Soil chemical characteristics used in this research

\begin{tabular}{ccccccccccc}
\hline $\begin{array}{c}\text { Sample } \\
\text { code }\end{array}$ & $\begin{array}{c}\text { Depth } \\
(\mathbf{c m})\end{array}$ & $\mathbf{p H}$ & $\begin{array}{c}\text { Org } \mathbf{C} \\
\mathbf{( \% )}\end{array}$ & $\begin{array}{c}\mathbf{N} \text { Total } \\
\mathbf{( \% )}\end{array}$ & $\begin{array}{c}\mathbf{C} / \mathbf{N} \\
\mathbf{r a t i o}\end{array}$ & $\begin{array}{c}\mathbf{P} \text { Total } \\
\mathbf{( \% )}\end{array}$ & $\begin{array}{c}\text { Cellulose } \\
\mathbf{( \% )}\end{array}$ & $\begin{array}{c}\text { Lignin } \\
\mathbf{( \% )}\end{array}$ & $\begin{array}{c}\text { Total } \\
\text { Cellulose } \\
\text {-Lignin }\end{array}$ & $\begin{array}{c}\text { Fiber } \\
\text { content }\end{array}$ \\
\hline GS & $0-20$ & 3.65 & 52.8 & 0.64 & 82.5 & 0.12 & 36.78 & 21.22 & 58.0 & 33.3 \\
& $20-40$ & 3.23 & 55.6 & 0.58 & 146.3 & 0.05 & 54,23 & 20.82 & 75.05 & 46.6 \\
& $40-60$ & 3.71 & 52.7 & 0.54 & 97.6 & 0.17 & 58.25 & 19.96 & 78.21 & 65.0 \\
& & & & & & & & & & \\
GNS & $0-20$ & 3.19 & 54.7 & 0.95 & 57.6 & 0.05 & 38.25 & 21.67 & 59.92 & 33.3 \\
& $20-40$ & 3.16 & 56.9 & 0.94 & 60.5 & 0.03 & 64.72 & 23.21 & 87.93 & 53.3 \\
& $40-60$ & 3.27 & 55.2 & 0.76 & 72.6 & 0.04 & 53.65 & 21.57 & 75.22 & 66.7 \\
& & & & & & & & & & \\
MS & $0-20$ & 4.22 & 4.7 & 0.16 & 29.4 & 0.02 & 16.59 & 10.82 & 27.41 & - \\
& $20-40$ & 3.92 & 2.0 & 0.07 & 28.6 & 0.01 & 16.75 & 15.91 & 32.66 & - \\
& $40-60$ & 3.75 & 0.9 & 0.05 & 17.6 & 0.0 & 16.30 & 15.18 & 31.48 & - \\
\hline
\end{tabular}

Notes: GS (peat-oil palm), GNS (peat-non oil palm), MS (mineral-oil palm) 

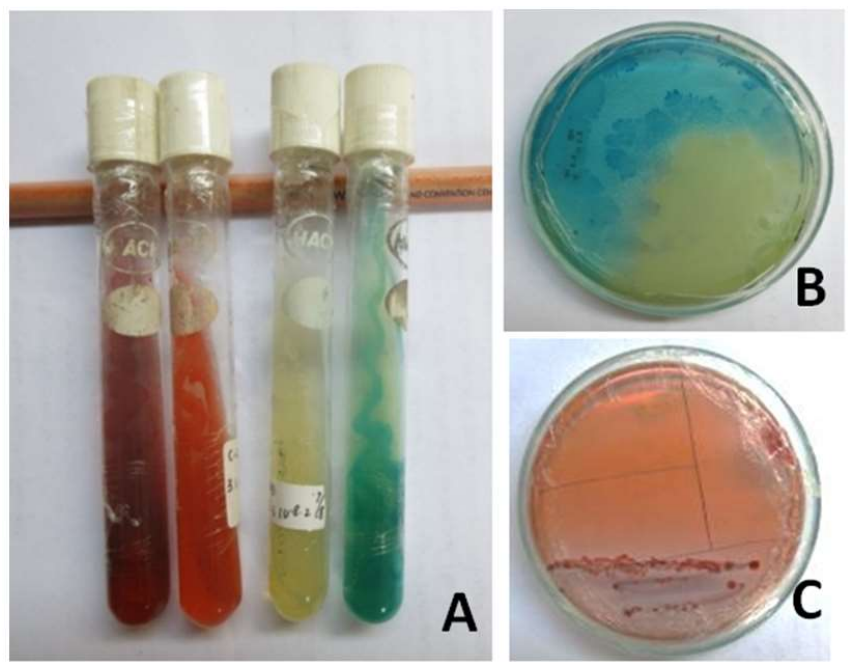

Fig 1 Pure culture of isolates used in respiration analyses. A) Pure culture of cellulolytic bacteria (1-2) and methylene blue degrading bacteria (3-4), B) Lignolytic bacteria ability in degrading methylene blue (blue medium turn to yellow) and C) Cellulolytic bacteria ability in degrading cellulose (clear zones formation).

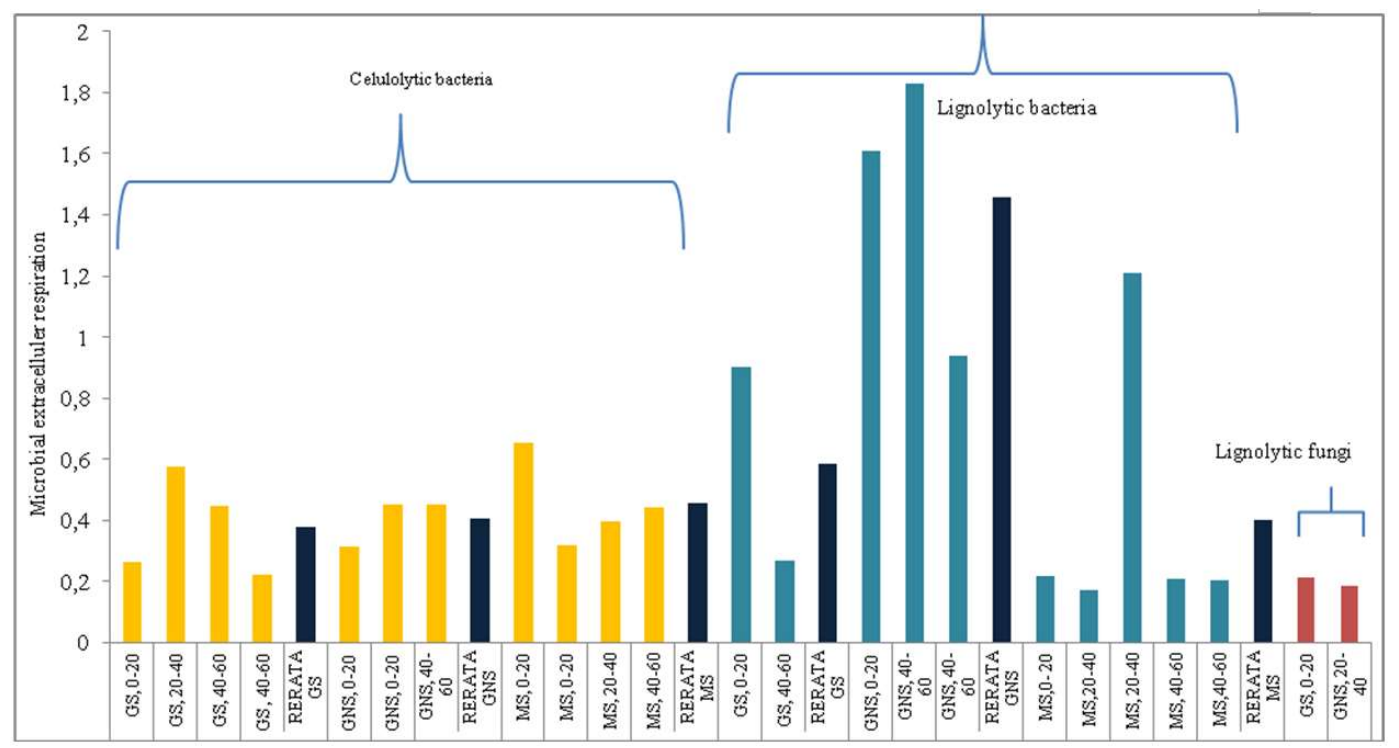

Fig 2 The respiration activities selected microorganism isolated from GS (peat-oil palm), GNS (peat-non oil palm, fern) and MS (mineral-oil palm).

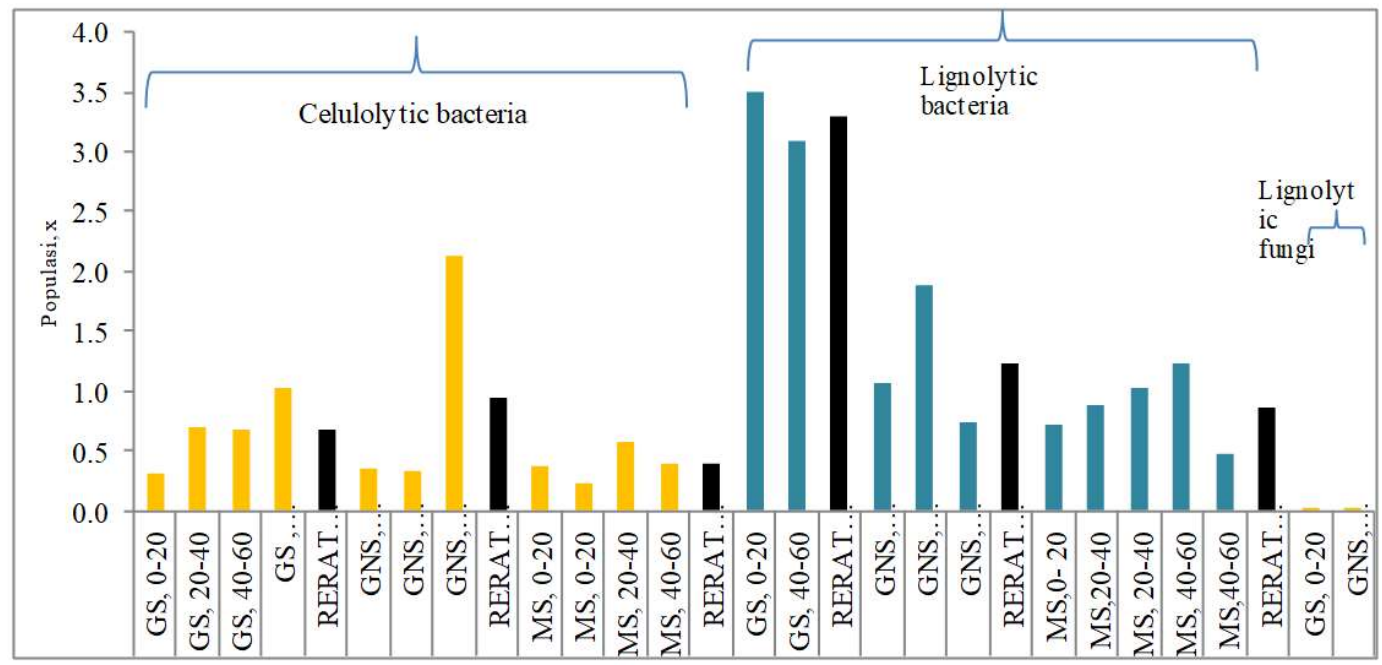

Fig 3 Population of each bacteria used in respiration analyses. 
The population of lignolytic fungi is much lower than that of cellulolytic bacteria and lignolytic bacteria. It showed that lygnolytic fungi need oxygen for their enzyme activity (Eischlerova et al. 2012). Though the content of lignin was higher with the depth but the oxygen content was seem likely more affect the activity of lignolityc microbe. In addition microbial population on peat is also influenced by peat origin and soil reaction. Tveit et al. (2012) suggested that bacteria are dominant in bog and are slightly found in fen which has acid reactions and in peat derived from sphagnum which has neutral reactions. Population ratio of fungi to bacteria is ranging from 0.31 to 0.68 while in peat originating from coniferous forests the ratio is above 1 which indicates that fungi dominate. The ratio of total fungal to bacteria of GS (peat-oil palm), GNS (peatnon oil palm), and MS (mineral-oil palm) was $1510^{-6}$, $2410^{-7}$, and $3810^{-6}$, respectively. It means that the ratio is less than 1 and the bacteria are dominant than fungi.

Lignolytic bacteria (methylene blue degradation bacteria) population in GNS is highest at $0-20 \mathrm{~cm}$ and decreases at subsequent depths. This study illustrated significant role of depth in microbial community structure, and thus we recommend the inclusion of this factor in future microbial ecological research in peatlands ecosystem. However, the population of these bacteria in oil palm mineral soils (MS) is higher compared to oil palm peat (GS) especially at depths of $40-60 \mathrm{~cm}$. The content of lignin was higher in GS compared to those in MS. It might be there is no correlation between the population of lignolytic bacteria and the content of the lignin since there is variation of lignin chemical structure or might be dissolved organic carbon (DOC) is more important than lignin content. Degree of decomposition and $\mathrm{pH}$ were found to be the major driving factors for DOC release (Schalm and Zeitz 2015).

The results of the study of Eslami et al. (2011) showed that there are two mechanism i.e. biodegradation and biosorption of methylene blue. In this study, the two mechanisms appear to occur simultaneously. At first the lignolytic isolate formed a yellow color which might indicate the degradation of methylene blue and then the colony changed to a bluer color which was thought to be the absorption of methylene blue. Habibi and Mehrabi (2017) also reported the degradation of methylene blue from Ralstonia eutropha. Its ability is greatly influenced by the presence of sugar, types of compounds $\mathrm{N}, \mathrm{pH}$ and $\mathrm{CuCl}_{2}$. The stages in Bacillus thuringiensis activity in methylene blue degradation are (1) biosorption of methylene blue in $\mathrm{Bt} 016$ biomass through electrostatic with chelating activity, (2) methylene blue subsequently degraded through enzyme activity along with metabolic processes. This is due to the presence of LiP and HRperoxidase enzymes. LiP enzyme is stable at $60^{\circ} \mathrm{C}$.

Respiration ability of each isolate varies both in the same functional group and between functional groups. In general, lignolytic fungi have the lowest respiration ability and are followed by cellulolytic bacteria. The respiration ability of lignolytic bacteria is strongly influenced by the origin of isolates and it seems that isolates originating from peat with non-oil palm vegetation have higher respiration ability compared to those from peat or mineral soils planted with oil palm.

Isolates derived from non-oil palm peat at a depth of 40-60 $\mathrm{cm}$ have the highest respiration while the lowest respiration ability is isolates from mineral soil isolated from a depth of $20-40 \mathrm{~cm}$. Soil respiration varies greatly and is influenced by availability of substrate, organic matter, temperature, humidity, availability of oxygen and nutrients, and soil characteristics (Truu et al. 2009; Bobul'ská et al. 2015; Yiqi and Zhou 2010). While Giorgio and Gasol (2010) suggested that microbial activity is influenced by $\mathrm{pH}$, temperature, rate of availability of organic compounds, their characteristics, and nutrient availability. Nevertheless, this respiration analysis also showed potential isolates. An interesting result in this study was that the highest respiration ability of lignolytic bacteria was shown by isolates isolated from peat soil that were not planted with oil palm but growing ferns. These results probably indicate that oil palm cultivation does not support growth and respiratory activity especially by lignolytic bacteria. Meanwhile, respiration of lignolytic bacteria isolated from mineral soils with oil palm vegetation was generally lower, except for lignolytic bacteria isolated from a depth of $20-40 \mathrm{~cm}$. Respiration ability of this isolates is almost equivalent to isolates isolated from peat soil with non-oil palm vegetation. The results in this study indicate that respiration is not affected by the origin of the isolate depth. The ability of bacteria originating from the surface layer, in this analysis is sometimes lower than that originating from deeper layers of soil. It supposed that the conditions when the bacteria lived more influential compared to the potential analyzed in this study. Results reported by Naconieczna and Sypniewski (2014) and Liu et al. (2016) showed that respiration activity in the surface layer was generally higher than in deeper layers because of the more 
available fresh materials (Keller and Takagi 2013; Fauzi et al. 2016). In deeper soil layers, lignin content is likely to be higher than at the surface. Lignin is a material that is quite resistant to decomposition. The analyses of lignin and cellulose in those three samples showed in Table 1.

The influence of roots can also affect the activity of respiration. The presence of roots results in higher microbial activity (Peterson 2003). In non-oil palm peat with fern vegetation, the lignin might has not been decomposed compared to oil palm which has deeper roots. Girkin et al. (2020) reported that roots exclude oxygen that affect the decomposition activities. Lignin is a material that is quite resistant to decomposition. In addition, samples in this study were taken in the oil palm area where there are very many active root hairs that exudate amino acids and other organic compounds that are very important for microbial activity in general. Also this area is an area where fertilization is a routine, so that it contains higher nutrients compared to peat with fern vegetation. In addition, samples from oil palm trees are more shaded so that they might be have lower temperatures compared to fodder vegetation that may affect in lignin decomposition. Nitrogen affects the decomposition of recalcitrant compounds. The addition of $\mathrm{N}$ will reduce its decomposition (Brouns et al. 2016). The effect of other nutrients in fertilizers such as $\mathrm{P}, \mathrm{K}, \mathrm{Ca}$ and $\mathrm{Mg}$, may also affect decomposition and respiration activities. In this research it showed that the content of $\mathrm{N}$ of mineral soil was lowest compared to the other two peat soils. Though the respiration activity of lignolytic bacteria isolated from GNS (peat-non oil palm) was higher compared to that isolated from MS (mineral-oil palm). Nitrogen was the core parameter correlating to microbial communities, but the interactive effects from various environmental variables displayed significant correlation to relative abundance of major microbial groups (Too et al. 2018). Quality and composition of organic matter, rather than tree species, demonstrated direct impact on the bacterial diversity (Millard and Singh 2010). Root inputs of oxygen varied significantly between species which, combined with different litter chemistry, exerts a key limitation on rates of decomposition. Differences between species are significant. Root oxygen mitigates methane fluxes in tropical peatlands (Girkin et al. 2020).

Lignolytic fungi population is very low and only found at certain depths. Actually this fungus has a higher ability to decompose lignin compared to bacteria, but bacteria have a diversity of lignolytic substrate that can be decomposed compared to fungi. Compared to other microorganism, it showed that there is only fungi that have extracellular lignin degrading enzymes such as laccase, Li-peroxidase and $\mathrm{Fe}$ peroxidase. The activity of these lignolytic enzymes will change lignin into an available form (Swift et al. 1979).

Lignolytic bacteria have a higher population than fungi and this is the same in all three habitats. More specifically, the population of lignolytic bacteria is much higher compared to cellulolytic bacteria. Lignolytic activity will help cellulolytic microbes in their activities due to the presence of lignin on the surface of the tissue (Pauly and Keegstra 2008). The results of research conducted by Winsborough and Basiliko (2010) show that bacteria are more active than fungi in many types of peat. Bacteria and fungi in their metabolism are chemoautotrophic. Heterotrophic microbes get carbon and energy together with the degradation of organic compounds present in the soil, including plant residues and dead microorganisms. Microbes in their activity also release extracellular enzymes into the environment that initiate the degradation of organic matter, which can be large and insoluble compounds to pass through the microbial membrane. This enzyme converts macromolecules into soluble forms that can be absorbed and metabolized by microbes (Bobul'ská et al.2015).

Bacteria and fungi are involved in the degradation of organic material in both aerobic and anaerobic conditions but fungi are more efficient than bacteria in the degradation of recalcitrant materials such as lignin because fungi produce extracellular enzymes that are more diverse than bacteria (Tveit et al. 2012). In mineral soils the population of lignolytic bacteria is more in deeper layers, possibly due to the presence of higher or accumulated lignin. Lignolytic bacteria population, dominant both on the surface and to a depth of $60 \mathrm{~cm}$.

Microbial composition of peat-oil palm, peat-non oil palm, and mineral-oil palm soils varies. The population of lignolytic fungi was rarely in contrast to lignolytic bacteria, while cellulolytic bacteria was found in all depth of each habitat. Respiration activities affected by functional and the origin of the isolate. Cellulolytic bacteria have low respiration activities compared to selected isolates of lignolytic bacteria. The lignolytic bacteria isolated from peat-non oil palm have the highest respiration activities. 


\section{ACKNOWLEDGEMENTS}

This study was part of a research funded by the Indonesian Palm Oil Plantation Fund Management Agency, the Ministry of Finance of the Republic of Indonesia with contract no PRJ-68/DPKS/2018.

\section{REFERENCES}

Adji, F F, Hamada,U. Darang, S.H. Limin and R. Hatano. 2014. Effect of plant-mediated oxygen supply and drainage on greenhouse gas emission from a tropical peatland in Central Kalimantan, Indonesia. Soil Scie Plant Nutr. 60(2), 216-230.

Berger, T. W., E. Inselsbacher, and S. ZechmeisterBoltenstern 2010, Carbon dioxide emissions of soils under pure and mixed stands of beech and spruce, affected by decomposing foliage litter mixtures, Soil Biol. Biochem., 42(6), 986-997.

Boggie, R. 1977. Water-table depth and oxygen content of deep peat in relation to root growth of Pinus contorta. Plant and Soil volume 48, pages447-454.

Bobul'ská L, Fazekašová D dan Angelovičová L 2015 Vertical profiles of soil properties and microbial activities in peatbog soils in Slovakia Environ Process. 2411-18

Brouns K., Joost A. Keuskamp, Gerrit Potkamp, Jos T.A. Verhoeven Mariet M. Hefting. 2016. Peat origin and land use effects on microbial activity, respiration dynamics and exo-enzyme activities in drained peat soils in the Netherlands Soil Biology and Biochemistry 95.

Davidson E and Janssens I 2006 Temperature sensitivity of soil carbon decomposition and feed-backs to climate change Nature 440 165-73.

Eichlerova I. , Baldrian P, Snajdr. 2012. Laccase activity in soils: Considerations for the measurement of enzyme activity. Chemosphere 88(10):1154-60.

Estop-Aragonés , C. and Klaus-Holger Knorr Christian Blodau. 2012. Controls on in situ oxygen and dissolved inorganic carbon dynamics in peats of a temperate fen. J. Geophysical Res. 17. GO2002 doi10.1029/2011 Jg001888.

Eslami, H., S. S. Khavidak, F. Salehi, R. Khosravi, R. Fallahzadeh, R. Peirovi, S. Sadegh. 2017. Biodegradation of methylene blue from aqueous solution by bacteria isolated from contaminated soil. J Adv. Environ Heath Res. 5, 10-15.

Fauzi Y, Widyastuti Y E, Satyawibawa I dan Hartono R 2006 2016 ? Oil Palm; Cultivation, Product and Waste Utilization, Business and Marketing Analyses Jakarta Indonesia Penebar Swadaya.
Fierer N, Craine J M, McLauchlan K and Schimel J P 2005 Litter quality and the temperature sensitivity of decomposition. Ecology 86320-6.

Giorgio PA, Gasol JM. 2010. Physiological structure and single-cell activity in marine bacterioplankton. In: Kirchman DR editor. Microbial Ecology of the Oceans, 2 st ed. NewYork JohnWiley\&Sons,Inc. 2008. pp. 243-298.

Girkin N. T. C. H Vane, B. L. Turner, N. J Ostle and S. Sjogersten. 2020. Root oxygen mitigates methane fluxes in tropical peatland. Environ. Res. Lett.

Habibi A. dan Z. Mehrabi. 2017. Aerobic degradation of methylene blue from colored effluents by Ralstonia eutropha . Polymer j. DOI 10.7508/PJ2017.03 Corpus ID 56027752 .

Jaatinen, K., Laiho, R., Vuorenmaa, A. Del Castillo, U. Minkkinen, K. Pennanen, T. Penttila, T. Fritze, H. . 2008. Responses of aerobic microbial community and soil respiration in water leveldrawdown in northernborreal fen. Environ. Microbiol. 10(2), 339353.

Jauhiainen J, Hooijer A and Page S E 2012a Carbon dioxide emissions from an Acacia plantation on peatland in Sumatra, Indonesia Biogeosciences 9 617-30.

Jauhiainen J, Silvennoinen H, Hämäläinen R, Kusin K, Limin S, Raison R J and Vasander H 2012b Nitrous oxide fluxes from tropical peat with different disturbance history and management Biogeosciences 9 1337-50.

Joosten , H. 2009. The Global Peatland CO2 Picture Peatland status and emissions in all countries of the world. Greifswald University Wetlands International, Ede, 2009 www.wetlands.org Produced for the UNFCCC meetings in Bangkok, September/October

Keller J K dan Takagi K K 2013 Solid-phase organic matter reduction regulates anaerobic decomposition in bog soil esa 4(5) 1-12.

Liu L, Chen H, Zhu Q, Yang G, Zhu E, Hu J, Peng C, Jiang L, Zhan W, Ma T, He Y dan Zhu D 2016 Response of peat carbon at different depth to simulated warming and oxidizing Sci Total Environ 548-549 429-40.

Millard P., Singh B. K. (2010). Does grassland vegetation drive soil microbial diversity? Nutr. Cycl. Agroecosyst. 88 147-158. 10.1007/s10705-009-9314-3.

Moore S, Evans C D, Page S E, Garnett M H, Jones T, Freeman C, Hooijer A, Wiltshire A J, Limin S H and Gauci V 2013 Deep instability of deforested tropical peatlands revealed by fluvial organic carbon fluxes Nature 493 660-3.

Nakonieczna A S dan Stêpniewska Z 2014 Aerobic and anaerobic respiration in profiles of polesie lubelskie peatlands Int Agrophys. 28 219-29.

Pauly M dan Keegstra K 2008 Cell-wall carbohydrates and 
their modification as a resource for biofuels Plant J 54 559-68.

Peterson E 2003 Importance of rhizodeposition in the coupling of plant and microbial productivity Eur J Soil Sci 54 741-50.

Schwalm, M., \& Zeitz, J. (2015). Concentrations of dissolved organic carbon in peat soils as influenced by land use and site characteristics - A lysimeter study. Catena, 127, 72-79.

Swift M J, Heal O W and Anderson J M 1979 Decomposition in Terrestrial Ecosystems, Berkeley CA University of California Press.

Too, C. C. A. Keller,Wi. Sickel, S.M. ee,dan C. M. Yule. 2018. Microbial Community Structure in a Malaysian Tropical Peat Swamp Forest: The Influence of Tree Species and Depth. Front Microbiol. . doi: 10.3389/fmicb.2018.02859.

Truu M, Juhanson J dan Truu J. 2009. Microbial biomass, activity and community composition in constructed wetlands Sci Total Environ. 4073958-71.

Tveit A, Schwacke R, Svenning M and Urich T 2012 Organic carbon transformations in higharctic peat soils: key functions and microorganisms The ISME J 7(2) 299311.

Wahyunto, Kusumo Nugroho, Sofyan Ritung, Yiyi Sulaeman. 2011. INDONESIAN PEATLAND MAP: METHOD, CERTAINTY, ANDUSES.

Wang X, Liu L, Piao S, Janssens I A, Tang J, Liu W, Chi Y, Wang J and Xu S 2014 Soil respiration under climate warming: differential response of heterotrophic and autotrophic respiration Glob. Change Biol. 20 3229-37.

Winsborough C, and N. Basiliko. 2010. Fungal and bacterial activity in Northern petaland. Geomicrobiology j. 27 (4),

Yiqi L dan X Zhou 2010 Soil Respiration and the Environment Elsevier Biodegradation of methylene blue from aqueous solution by bacteria isolated from contaminated soil . JAdv. Evironm health res. 5, 10-15.

Zhou, J. Wen, .J. C. and Q. Lu. 2015. Rapid Measurement of Microbial Extracellular Respiration Ability Using a High-Throughput Colorimetric Assay . Environmental Sci and Tech Letters. 